\title{
KINETIKA VULKANISASI CAMPURAN NR/EPDM DENGAN PENDEKATAN MODEL DENG-ISAYEV DAN KAMAL-SOROUR
}

\section{KINETICS STUDIES OF NR/EPDM BLENDS VULCANIZATION BASED ON DENG-ISAYEV AND KAMAL-SOROUR MODELS}

\author{
Ihda Novia Indrajati*, Muhammad Sholeh \\ Balai Besar Kulit, Karet, dan Plastik, Jl. Sokonandi No. 9 Yogyakarta 55166, Indonesia. \\ * Penulis korespondensi. Telp.: +62 274 512929, 563939; Fax.: +62 274563655 \\ E-mail: i-novia@kemenperin.go.id
}

Diterima: 25 Agustus 2014 Direvisi: 26 November $2014 \quad$ Disetujui: 1 Desember 2014

\begin{abstract}
Curing kinetics of natural rubber/ethylene propylene diene monomer (NR/EPDM) blends at different ratios of 2,2'-dithiobis(benzothiazole) (MBTS) and zinc diethyl dithiocarbamate (ZDEC) were studied. NR/EPDM blends were prepared using curative migration control technique. Kinetics studies employ Deng-Isayev and Kamal-Sorour models and kinetics parameters were evaluated using measured data from Moving Die Rheometer. Rate constant $(k)$ and orders of reaction ( $n$ and $m$ ) were estimated through multivariable optimization using Matlab and activation energy (E) was determined using Arrhenius relationship. From the results, it is evident that the experimental data were in a good agreement with Kamal-Sorour model. It is also found that autocatalytic mechanism was more controlling than the others as indicated by $k_{2}>k_{1}$. Results also shows that rate constants were greatly influenced by temperature and the types of accelerator, while orders of reaction were dependent on temperature and independent on the types and amounts of accelerator. Combination of MBTS and ZDEC reduces energy activation of autocatalytic reaction. For desirable rate of curing, its ratio of 1.4 to 0.2 gave the lowest activation energy.
\end{abstract}

Keywords: kinetics study, vulcanization, NR/EPDM, Deng-Isayev, Kamal-Sorour.

\begin{abstract}
ABSTRAK
Kinetika vulkanisasi campuran NR/EPDM pada berbagai rasio MBTS/ZDEC dipelajari dalam publikasi ini berdasarkan data output Moving Die Rheometer (MDR). Campuran NR/EPDM dibuat dengan teknik kontrol migrasi curatives. Pendekatan yang digunakan adalah model empiris Deng-Isayev dan Kamal-Sorour. Konstanta kecepatan reaksi $(k)$ dan orde reaksi ( $n$ dan $m$ ) ditentukan dengan optimasi multivariabel menggunakan perangkat lunak Matlab. Energi aktivasi (E) ditentukan dengan hubungan Arrhenius. Hasil studi menunjukkan data eksperimen dapat dideskripsikan dengan baik oleh model Kamal-Sorour. Mekanisme autokatalitik mendominasi mekanisme lainnya ditunjukkan dengan $k_{2}>k_{1}$. Konstanta kecepatan reaksi bergantung pada suhu dan jenis akselerator, sedangkan orde reaksi tidak tergantung pada suhu tetapi pada jenis dan jumlah akselerator. Kombinasi akselerator MBTS dan ZDEC menurunkan energi aktivasi reaksi autokatalisis. Rasio 1,4/0,2 merupakan kombinasi yang memberikan energi aktivasi cukup rendah dengan kecepatan reaksi yang tinggi.
\end{abstract}

Kata kunci: kinetika, vulkanisasi, NR/EPDM, Deng-Isayev, Kamal-Sorour.

\section{PENDAHULUAN}

Sifat mekanik produk akhir barang karet sangat dipengaruhi oleh derajat vulkanisasinya (Wu et al., 2013; Arrilaga et al., 2007). Vulkanisasi kompon karet merupakan reaksi bertingkat yang kompleks antara karet dengan bahan-bahan komponding, mengarah pada sifat-sifat psiko-mekanikal yang bervariasi. Reaksi vulkanisasi melibat- kan suplai energi untuk mengubah kompon (unformed elastomer) menjadi produk yang elastis, sehingga biaya produk akhir secara langsung berkorelasi dengan konsumsi energi selama vulkanisasi. Jika vulkanisasi berlangsung terlalu cepat akan meningkatkan viskositas karet dan menghambat aliran kompon yang menimbulkan cacat (scorch). Sebaliknya, bila berjalan sangat lambat 
maka produktivitas akan menurun (Yeoh, 2012). Pembentukan ikatan silang (crosslinking) pada campuran polimer merupakan fenomena kompleks yang diatur oleh beberapa faktor, seperti karakteristik kimia dan fisika komponen polimer dalam campuran, zat pemvulkanisasi, waktu, dan suhu vulkanisasi (Bianchi et al., 2009).

Studi kinetika vulkanisasi memberikan informasi proses pematangan yang dapat digunakan sebagai dasar mengontrol dan mengoptimasi siklus pematangan sehingga diperoleh kematangan yang seragam pada produk karet, mencapai kematangan yang ekivalen dan mendapatkan kematangan yang cukup untuk produk yang tebal (Arillaga et al., 2007; Khang \& Ariff, 2012; Ahmadi \& Shojaei, 2013). Studi tersebut juga menghasilkan koefisien kinetika yang diperlukan sebagai masukan bagi model matematika untuk memprediksi respon kompon karet terhadap deformasi yang muncul selama pemrosesan (Khang \& Ariff, 2012). Implementasi model kinetika memberikan deskripsi terinci mengenai karakteristik pematangan sehingga akan diperoleh pemahaman mendalam terkait struktur mikro kompon karet (Ahmadi \& Shojaei, 2013). Arrilaga et al. (2007) menyatakan komposisi kompon karet, suhu pengujian, dan metode yang digunakan untuk mengkarakterisasi material merupakan faktor-faktor yang mempengaruhi kinetika vulkanisasi.

Vulkanisasi karet dapat dipelajari melalui analisis kimia, differential scanning calorimetry (DSC), oscillating disc rheometry (ODR), dan moving die rheometry (MDR) (Arrilaga et al., 2007; Khang \& Ariff, 2012). Teknik rheometrik menunjukkan bahwa kekakuan (stiffness) karet dan perubahannya selama pematangan (curing) isotermal berhubungan dengan konversi vulkanisasi $(\alpha)$. Oleh karena itu, derajat kematangan merupakan parameter penting untuk mengamati sejauh mana proses pematangan, dan bervariasi menurut waktu vulkanisasi (Allahbakhsh et al., 2013). Kerapatan ikatan silang pada karet umumnya meningkat perlahan selama periode induksi, kemudian meningkat dengan cepat ketika reaksi vulkanisasi utama berlangsung. Setelah mencapai nilai maksimum kemudian mulai menurun, berlawanan dengan polimer termoset pada umumnya yang kerapatan ikatan silang akan naik secara monotonik selama pematangan hingga nilai maksimum akhir (Leroy et al., 2013a). Derajat kematangan atau konversi $(\alpha)$ didefinisikan oleh persamaan (1) (Marzocca \& Mansilla, 2006; Khang \&
Ariff, 2012).

$\alpha=\frac{M t-M L}{M H-M L}$

$M t, M L$ dan $M H$ secara berurutan adalah torsi pada waktu $t$, torsi minimum dan torsi maksimum.

Pemodelan karakteristik vulkanisasi meliputi dua model kinetik mekanistik dan fenomenologi atau empiris. Model mekanistik mendeskripsikan reaksi kimia yang terjadi pada proses pematangan (Arrilaga et al., 2007; Allahbakhsh et al., 2013), sedangkan model fenomenologi menggunakan regresi non-linier untuk mencocokan (fitting) data percobaan untuk menentukan parameter utama (Arrilaga et al., 2007).

Reaksi kimia secara umum dapat dimodelkan dalam persamaan diferensial seperti pada persamaan (2) (Yeoh, 2012; Akhlaghi et al., 2012; Wu et al., 2013).

$\frac{d \alpha}{d t}=k(T) f(\alpha)$

$\alpha$ merupakan fraksi reaksi (konversi), nilainya $0<\alpha<1, t$ adalah waktu reaksi, $k(T)$ merupakan konstanta kecepatan reaksi dan $f(\alpha)$ adalah model kinetika. Konstanta kecepatan reaksi $(k(T))$ bergantung pada suhu dan diasumsikan mengikuti hubungan Arrhenius yang dinyatakan dalam persamaan (3)

$$
k=A \exp \left(\frac{-E}{R T}\right)
$$

A, E, dan R secara berurutan adalah faktor kecepatan reaksi, energi aktivasi dan tetapan gas. Mekanisme reaksi pematangan, baik mekanistik maupun fenomenologi, akan mempengaruhi $f(\alpha)$. Model mekanistik memberikan prediksi dan intepretasi yang cukup terhadap kecepatan pematangan, namun perlu diketahui secara tepat komposisi kimia reaktan secara tepat selama proses pematangan, serta perincian sepesies reaktif yang terlibat dalam reaksi. Kompleksitas tersebut menjadikan pendekatan fenomenologi lebih disukai karena lebih sederhana (Akhilaghi et al., 2012).

Dalam model fenomenologi terdapat dua mekanisme yang menggambarkan proses pematangan polimer termoset, yaitu model orde ke- $n$ dan autokatalisis. Model orde ke- $n$ mengasumsikan bahwa kecepatan reaksi sebanding dengan konsentrasi yang tidak bereaksi (1- $\alpha$ ) seperti dinyatakan dalam persamaan (4) (Kalaee et al., 2011). Sedangkan pada model autokatalisis, konversi se- 
banding dengan konsentrasi bahan yang tidak bereaksi maupun yang bereaksi seperti ditunjukkan pada persamaan (5) (Kalaee et al., 2011; Akhilaghi et al., 2012).

$\frac{d \alpha}{d t}=k(1-\alpha)^{n}$

$\frac{d \alpha}{d t}=k(1-\alpha)^{n} \alpha^{m}$

$n$ dan $m$ merupakan orde reaksi. Model orde ke- $n$ tidak cukup menggambarkan jalannya reaksi secara lengkap karena beberapa reaksi dapat berjalan secara simultan (Kalaee et al., 2011; Yeoh, 2012). Untuk pematangan isotermal, model orde ke- $n$ memprediksi kecepatan reaksi maksimum pada $t=0\left(t_{0}\right)$, sedangkan menurut model autokatalisis kecepatan reaksi maksimum dapat terjadi pada $t>t_{0}$. Pada reaksi autokatalisis produk reaksi pematangan dapat mengkatalisis reaksi selanjutnya (Kalaee et al., 2011; Akhilaghi et al., 2012).

Kamal dan Sorour (Yeoh, 2012; Leroy et al., 2013a) menyusun model empiris yang merupakan gabungan antara model orde ke- $n$ dan autokatalisis, seperti dinyatakan pada persamaan (6).

$$
\frac{d \alpha}{d t}=\left(k_{1}+k_{2} \alpha^{m}\right)(1-\alpha)^{n}
$$

$k_{1}$ dan $k_{2}$ secara berurutan adalah konstanta kecepatan reaksi orde ke- $n$ dan autokatalisis, sedangkan $m$ dan $n$ merupakan orde reaksi. Deng dan Isayev menyusun model lain dimana derajat kematangan $(\alpha)$ untuk pematangan isotermal dinyatakan dalam suatu hubungan seperti pada persamaan (7) (Khang \& Ariff, 2012; Allahbakhsh et al., 2013) dan kecepatan reaksi pematangan dinyatakan pada persamaan (8) (Leroy et al., 2013a; Yeoh, 2012).

$$
\begin{aligned}
\alpha & =\frac{k\left(t-t_{s 2}\right)^{n}}{1+k\left(t-t_{s 2}\right)^{n}} \\
\frac{d \alpha}{d t} & =\left[\alpha^{\frac{n-1}{n}}(1-\alpha)^{\frac{n+1}{n}} n k^{\frac{1}{n}}\right]
\end{aligned}
$$

$k$, $t s_{2}$, dan $n$ secara berurutan adalah konstanta kecepatan reaksi, waktu scorch dan orde reaksi. Kedua model tersebut dapat digunakan untuk menganalisis proses vulkanisasi sulfur pada periode pematangan, namun tidak sesuai untuk periode induksi atau sebelum dicapai waktu scorch $\left(t s_{2}\right)$. Periode tersebut berhubungan dengan viskositas kompon sehingga tidak dapat diikutsertakan dalam optimasi karena diatur oleh mekanisme fisis (Milani \& Milani, 2013) dan kimia akselerator memegang peranan utama dalam proses pada periode tersebut (Marzocca \& Mansilla, 2006). Kedua model juga disusun dengan mengabaikan fenomena reversion (Leroy et al., 2013b).

Informasi parameter kinetika reaksi vulkanisasi campuran NR/EPDM sangat terbatas. Beberapa publikasi telah mempelajari kinetika vulkanisasi NR (Wu et al., 2013; Khang \& Ariff, 2012) dan EPDM (Allahbakash et al., 2013; Akhilagi et al., 2012) secara terpisah dengan menggunakan pendekatan model Kamal-Sorour maupun Deng-Isayev. Milani and Milani (2013) menggunakan pendekatan finite element model untuk mengoptimasi vulkanisasi sulfur pada karet EPDM. Kinetika vulkanisasi campuran NR/SBR (styrene butadiene rubber) dipelajari oleh Ahmadi and Sojaei (2013). Publikasi ini akan mempelajari parameter kinetika reaksi vulkanisasi yang meliputi konstanta kecepatan reaksi, orde reaksi dan energi aktivasi campuran NR/EPDM pada berbagai rasio MBTS/ZDEC menggunakan pendekatan model empiris Deng-Isayev dan Kamal-Sorour berdasar data rheometrik menggunakan moving die rheometer (MDR).

\section{BAHAN DAN METODE Bahan Penelitian}

Bahan penelitian terdiri atas karet alam jenis pale crepe yang diperoleh di pasaran, karet EPDM jenis Keltan 4551 A, high abrasion furnace (HAF) Black Ex.OCI, general purpose furnace (GPF) Black Ex.Korea, castor oil (Bratachem), polimer 2,2,4-Trimethyl-1,2dihydroquinoline (TMQ) Ex.Kemai, paraffin wax Antilux 654A, $\mathrm{ZnO}$ (Bratachem), Aflux 42M,2,2'dithiobis(benzothiazole) (MBTS) Ex.Shandong Sianxian, zinc diethyl dithiocarbamate (ZDEC), sulfur SP-325 Ex.Miwon, maleat anhidrida (MAH) dan dicumyl peroxide (DCP).

\section{Peralatan Penelitian}

Peralatan yang digunakan dalam penelitian ini meliputi two roll mill skala laboratorium, moving die rheometer (MDR) Gotech 3000A, dan perangkat lunak MATLAB 5.3.

\section{Metode Penelitian \\ Eksperimen dan pengambilan data mentah}

Kompon NR/EPDM yang digunakan dibuat dengan teknik seperti diuraikan pada publikasi 
Tabel 1. Rasio MBTS/ZDEC.

\begin{tabular}{ccc}
\hline \multirow{2}{*}{ Kode } & \multicolumn{2}{c}{ Akselerator $(\mathrm{phr})$} \\
\cline { 2 - 3 } & MBTS & ZDEC \\
\hline R1 & 1,6 & 0,0 \\
R2 & 1,5 & 0,1 \\
R3 & 1,4 & 0,2 \\
R4 & 1,3 & 0,3 \\
R5 & 1,2 & 0,4 \\
\hline
\end{tabular}

sebelumnya (Indrajati \& Sholeh, 2014), dengan komposisi bahan meliputi pale crepe (60 phr), EPDM (40 phr), ZnO (5 phr), Aflux (1 phr), HAF (40 phr), GPF (50 phr), TMQ (1 phr), paraffin wax $(0,5 \mathrm{phr})$, castor oil ( $5 \mathrm{phr})$, sulfur (1 phr), MAH (3 phr), DCP (0,9 phr). Akselerator MBTS dan ZDEC divariasikan sesuai dengan Tabel 1.

Vulkanisasi isotermal kompon NR/EPDM dipelajari pada suhu $160^{\circ} \mathrm{C}(433 \mathrm{~K}), 170^{\circ} \mathrm{C}(443 \mathrm{~K})$ dan $180^{\circ} \mathrm{C}(453 \mathrm{~K})$ menggunakan rheometer tipe MDR. MDR terdiri dari sebuah ruangan tertutup dengan die bawah berosilasi sinusoidal, sedangkan sistem pengukuran torsi berada pada die atas. Oleh karena itu dapat diukur respon viskoelastik bahan selama vulkanisasi. Ruangan tertutup pada rheometer menjadikan pengukuran reologikal dilakukan pada kondisi yang mendekati proses pencetakan, yaitu pada cetakan tertutup tanpa adanya kontak dengan udara, sehingga terhindar dari pengusangan oksidatif selama pengukuran (Leroy et al, 2013a). Data yang diperoleh dari pengukuran pada masing-masing suhu meliputi torsi maksimum $(M H)$, torsi minimum $(M L)$, torsi pada waktu tertentu $(M t)$, waktu scorch $\left(t s_{2}\right)$ dan waktu optimum vulkanisasi $\left(t_{90}\right)$. Data tersebut digunakan untuk menghitung parameter kinetika vulkanisasi.

\section{Pencocokan (fitting) model}

Data output MDR diolah untuk mendapatkan $\alpha$ eksperimen $\left(\alpha_{e}\right)$ menggunakan persamaan 1, sedangkan parameter vulkanisasi $(k, k, k, n$, dan $m)$ ditentukan menggunakan optimasi multivariabel dengan tools Fminsearch pada perangkat lunak Matlab 5.3. Algoritma optimasi model DengIsayev dan Kamal-Sorour disajikan pada Gambar 1. Toleransi sum of squared error (SSE) memakai default dari software.

Orde reaksi $(n)$ pada model Deng-Isayev diasumsikan tidak berubah terhadap suhu tetapi berubah terhadap formulasi kompon (Khang \& Ariff, 2012) seperti jumlah sulfur dan akselerator

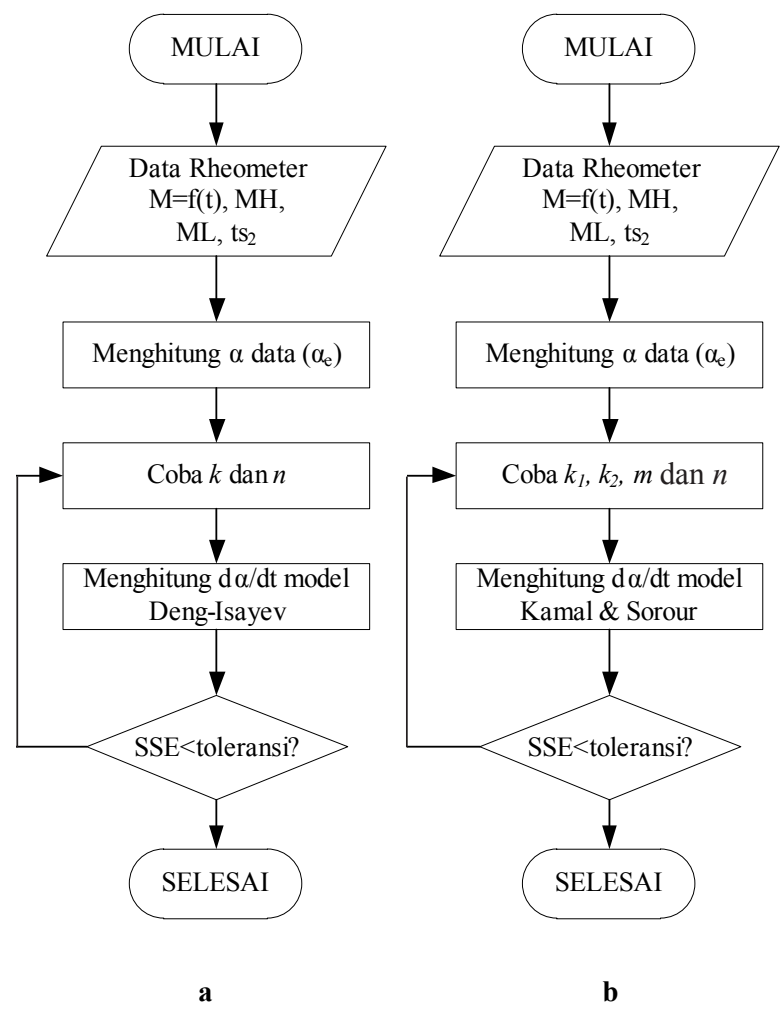

Gambar 1. Algoritma optimasi model (a) DengIsayev, (b) Kamal-Sorour.

pada masing-masing kompon (Marzocca \& Mansilla, 2006). Konstanta kecepatan reaksi (k) pada berbagai suhu kemudian digunakan untuk menghitung energi aktivasi $(E)$ dan faktor kecepatan reaksi $(A)$ menggunakan persamaan (5) dengan regresi linier.

\section{HASIL DAN PEMBAHASAN \\ Kurva Rheometer dan Karakteristik Vul- kanisasi}

Gambar 2 menunjukkan pengaruh suhu dan rasio MBTS/ZDEC pada kurva rhoemeter NR/ EPDM. Pada suhu tinggi $\left(180^{\circ} \mathrm{C}\right)$ dan pada seluruh variasi komposisi MBTS/ZDEC ditemui fenomena dimana harga torsi meningkat dengan bertambahnya waktu, kemudian menurun setelah mencapai waktu tertentu. Dari Gambar 2(a)-(e) dapat dilihat bahwa variasi komposisi MBTS/ ZDEC tidak menghilangkan fenomena reversion, namun mempengaruhi kecepatan terjadinya reversion, yaitu semakin kecil komposisi ZDEC reversion semakin cepat terjadi. Reversion muncul sebagai akibat adanya reaksi desulfurisasi, misalnya pemutusan ikatan polisulfida menjadi ikatan yang lebih stabil mono- dan disulfida (Ahmadi \& Shojaei, 2013; Leroy et al., 2013b). Reversion dapat 


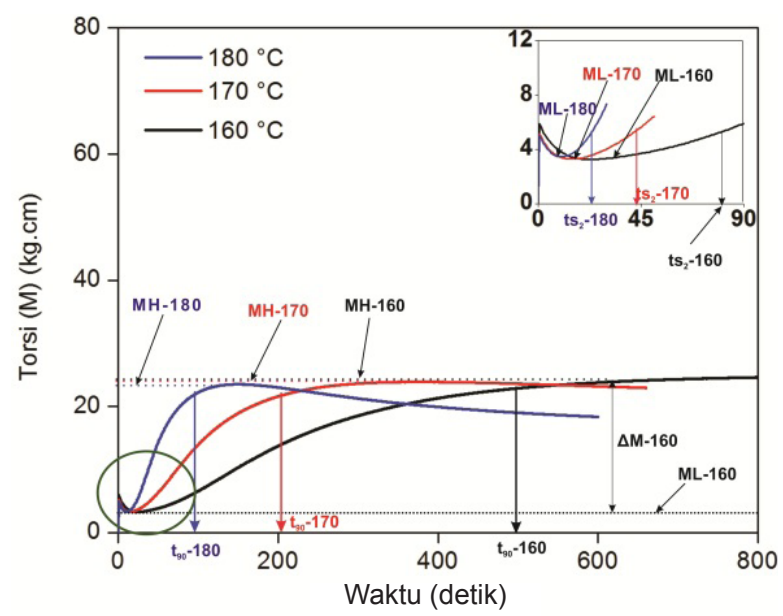

(a)

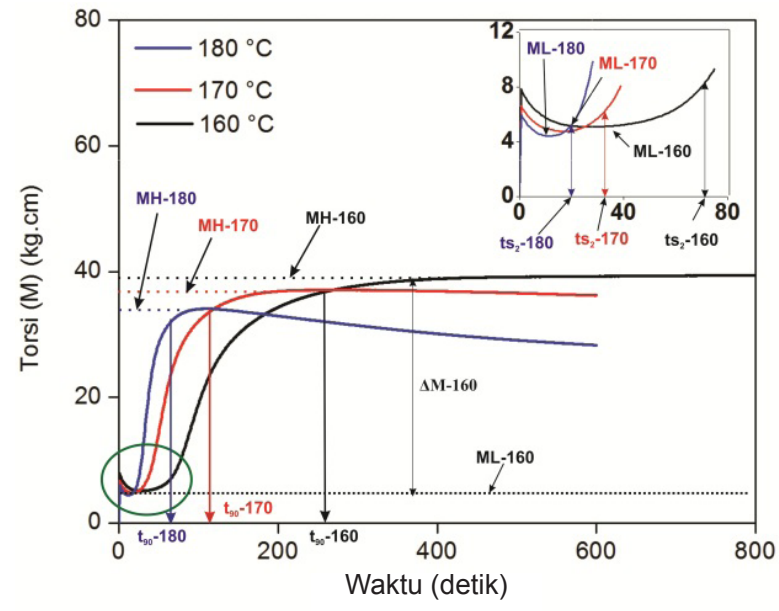

(c)

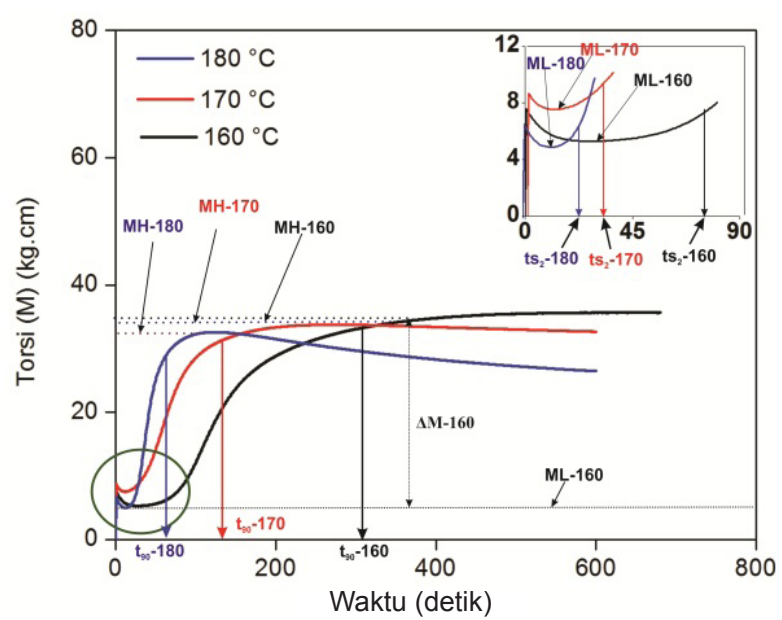

(b)

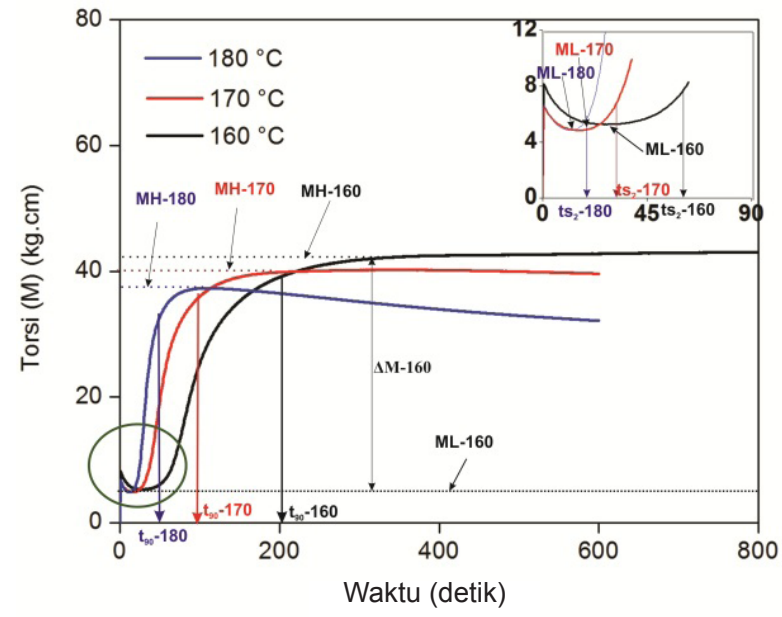

(d)

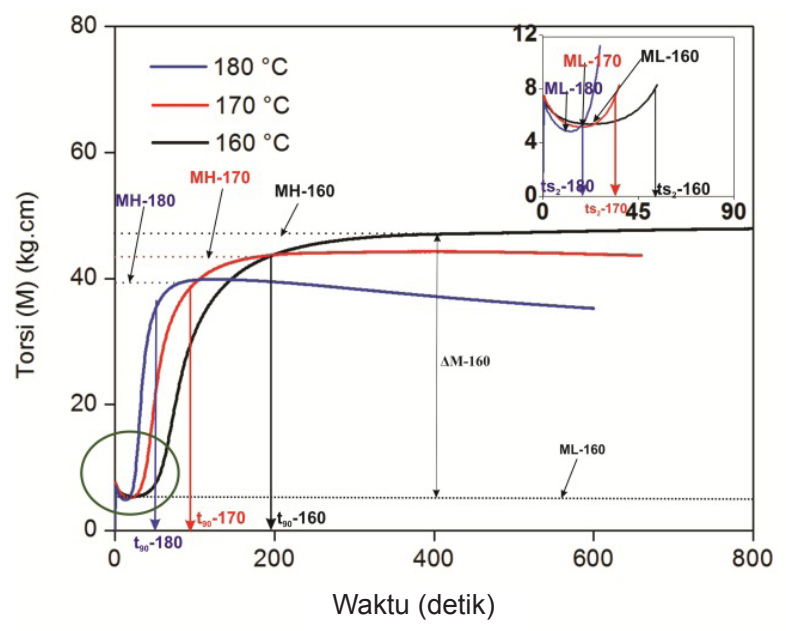

(e)

Gambar 2. Kurva rheometer (a) R1, (b) R2, (c) R3, (d) R4, dan (e) R5.

pula disebabkan oleh percepatan transformasi unit isomer cis pada NR menjadi struktur trans yang mempunyai ketahanan reversion rendah pada suhu tinggi (Ahmadi \& Shojaei, 2013).
Kurva pada Gambar 2(a)-(e) menunjukkan bahwa pada suhu tinggi $t s_{2}$ (inset) dan $t_{90}$ berkurang untuk seluruh komposisi MBTS/ZDEC. Menurut Allahbakhsh et al. (2013) penurunan $t_{90}$ dengan 
meningkatnya suhu merupakan karakteristik endotermik proses pematangan karet jenuh. Pergerakan molekul meningkat pada suhu tinggi dan mendorong reaksi berjalan lebih cepat. Pada kondisi tersebut jaringan ikatan silang yang dibentuk menjadi lebih sedikit, ditunjukkan dengan penurunan $M H$ dan $t_{90}$ yang lebih singkat. Semakin besar komposisi ZDEC juga menyebabkan penurunan $t_{2}$ dan $t_{90^{\circ}}$. Teknik komponding reaktif dengan kontrol migrasi curative yang digunakan pada penelitian ini telah menghasilkan ikatan silang parsial pada tahap awal (pemanasan awal kompon EPDM) sehingga spesies aktif yang terlibat dalam vulkanisasi final semakin sedikit. Akibatnya waktu yang dibutuhkan untuk mencapai konversi maksimal lebih cepat. Penjelasan lebih lanjut mengenai teknik tersebut dipaparkan pada publikasi sebelumnya (Indrajati \& Sholeh, 2014). Menurut Allahbakhsh et al. (2013) penurunan $\mathrm{t}_{90}$ dengan meningkatnya suhu merupakan karakteristik endotermik proses pematangan karet jenuh.

$M L$ merupakan torsi pada saat belum terjadi reaksi vulkanisasi sehingga dapat merupakan pengukuran viskositas kompon (uncured). Kenaikan suhu mengakibatkan $M L$ menurun dan semakin besar komposisi ZDEC memperbesar penurunan tersebut. Di sisi lain pada suhu yang sama kenaikan komposisi ZDEC meningkatkan $M L$. Selisih $M H-M L(\Delta M)$ merepresentasikan modulus gesek (shear modulus) yang secara tidak langsung berhubungan dengan kerapatan ikatan silang yang terbentuk (Indra et al., 2013; Ahmad \& Shojaei, 2013). $\Delta M$ seluruh komposisi MBTS/ZDEC menurun dengan kenaikan suhu. Penggunaan akselerator tunggal (R1) memberikan $M L$ lebih rendah daripada akselerator kombinasi (R2-R5), dan semakin besar komposisi ZDEC menyebabkan kenaikan $M L, M H$ serta $\Delta M$. Elemen elastis mendominasi campuran NR/EPDM dengan akselerator MBTS/ZDEC sebagai efek dari teknik reaktif yang digunakan dalam proses komponding. Teknik reaktif dengan kontrol migrasi curative yang digunakan pada penelitian ini menghasilkan ikatan silang parsial pada kompon EPDM sebelum dicampur dengan NR seperti dipaparkan pada publikasi terdahulu (Indrajati \& Sholeh, 2014). Pada proses tersebut, telah terbentuk ikatan silang parsial pada fasa EPDM sebelum dicampur dengan NR sehingga diperoleh distribusi ikatan silang yang lebih homogen. Elemen elastis mendominasi fase kompon menyebabkan viskositasnya besar. Kombinasi MBTS/ZDEC memberi efek aktivitas yang sinergi sehingga menghasilkan kerapatan ikatan silang lebih tinggi.

\section{Kinetika Kecepatan Reaksi}

Derajat kematangan (degree of cure) atau konversi $(\alpha)$ menggambarkan jumlah ikatan silang yang terbentuk pada waktu tertentu. Derajat kematangan dihitung menggunakan persamaan (1) dan Gambar 3 menunjukkan hubungan $\alpha$ hasil eksperimen $\left(\alpha_{e}\right)$ terhadap waktu $(t)$.

Seluruh campuran NR/EPDM (Gambar 3(a)-(e)) pada berbagai komposisi MBTS/ZDEC menunjukkan pola hubungan $\alpha$ terhadap $t$ yang serupa untuk ketiga suhu vulkanisasi. Menurut Janković (2010), pada Gambar 3 dapat dilihat bahwa setelah periode induksi kecepatan konversi meningkat secara cepat (periode akselerasi), diikuti dengan penurunan kecepatan secara progresif (periode deselerasi) hingga kurva mencapai nilai maksimum (mendatar). Pada suhu yang rendah konversi bergerak lebih lambat sehingga dibutuhkan waktu lebih lama untuk mencapai kematangan $100 \%(\alpha \approx 1)$. Lambatnya laju konversi berkaitan dengan laju reaksi vulkanisasi. Wu et al. (2013) menyatakan bahwa ketika kompon yang mengandung pemvulkanisasi dikenai panas maka akselerator, aktivator, dan sulfur akan mendifusi kedalam matriks karet dan bereaksi satu sama lain membentuk spesies polisulfida. Spesies tersebut kemudian mendifusi untuk berkontak dan bereaksi dengan ikatan rangkap yang tidak jenuh pada karet membentuk titik ikatan silang. Teknik kontrol migrasi curative menghasilkan ikatan silang parsial berupa fragmen kompleks akselerator-sulfur yang menempel pada rantai molekul EPDM (Indrajati \& Sholeh, 2014). Sehingga pada vulkanisasi final spesies inilah yang akan mendifusi kedalam fase NR. Mobilitas rantai molekul karet pada suhu rendah terjadi secara lambat, demikian pula dengan difusi spesies aktif sehingga kontak akan lebih baik. Ikatan silang yang terbentuk menjadi lebih banyak meskipun dengan waktu optimum yang lebih panjang. Ikatan silang yang semakin rapat akan menaikkan viskositas sehingga memperlambat pembentukan ikatan silang. Oleh karena itu laju konversi berjalan lambat.

Kenaikan suhu vulkanisasi meningkatkan laju konversi yang ditandai oleh kemiringan kurva yang lebih terjal. Pada suhu tinggi mobilitas molekul dan difusi spesies aktif meningkat sehingga dapat dengan cepat membentuk jaringan ikatan silang tetapi menghasilkan rantai yang pendek. Oleh 


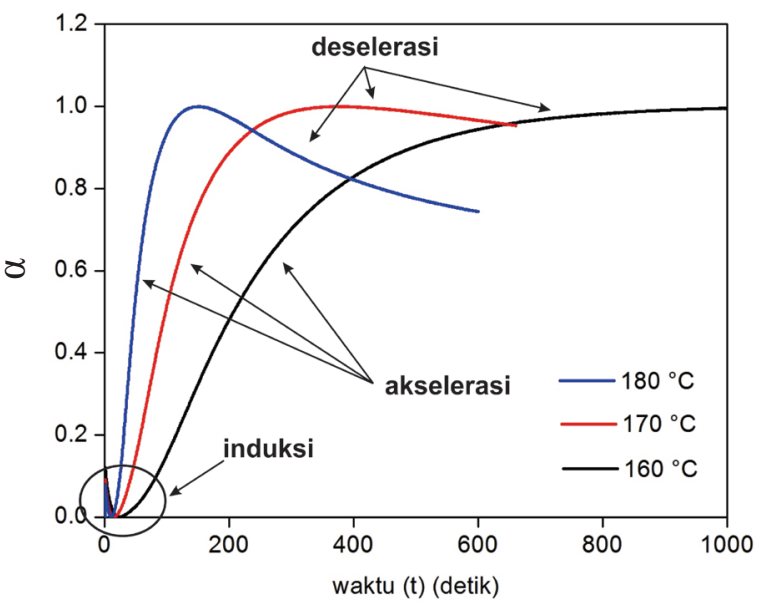

(a)

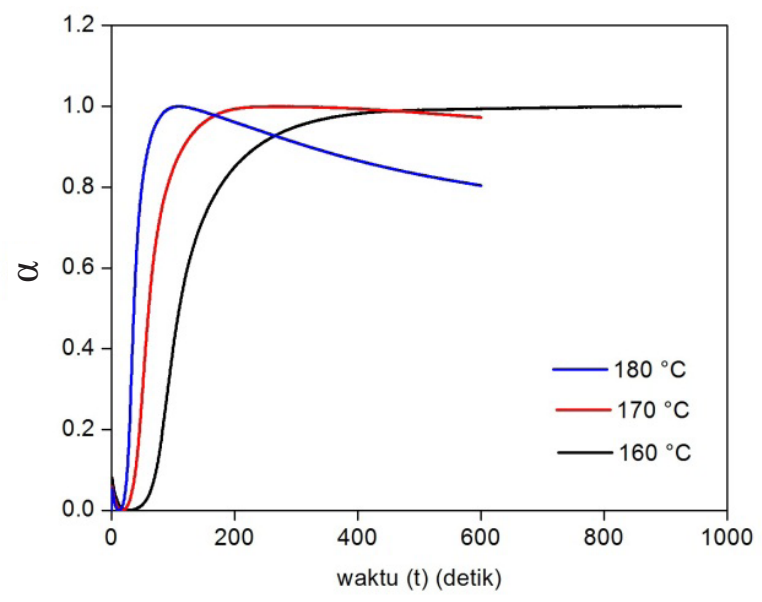

(c)

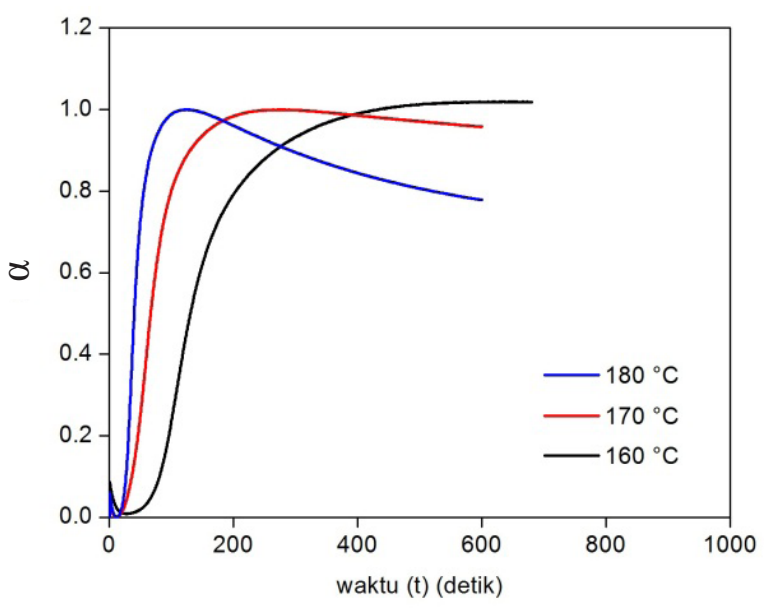

(b)

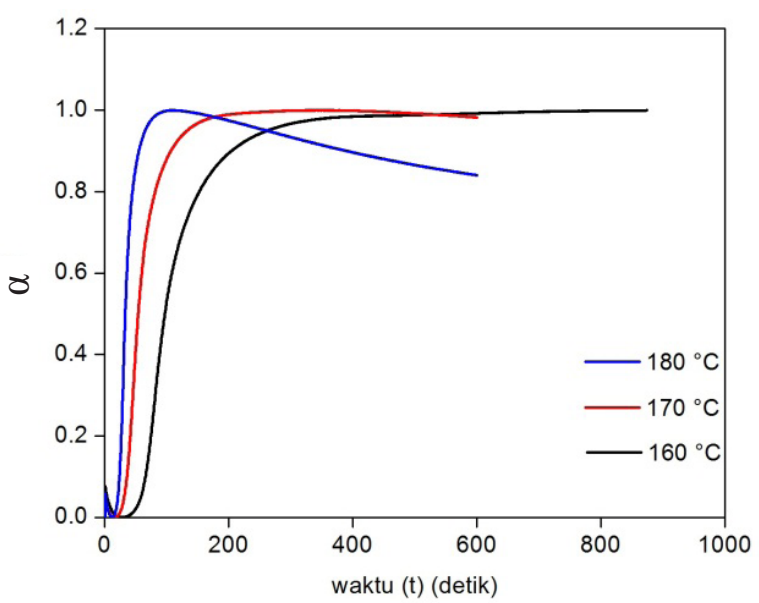

(d)

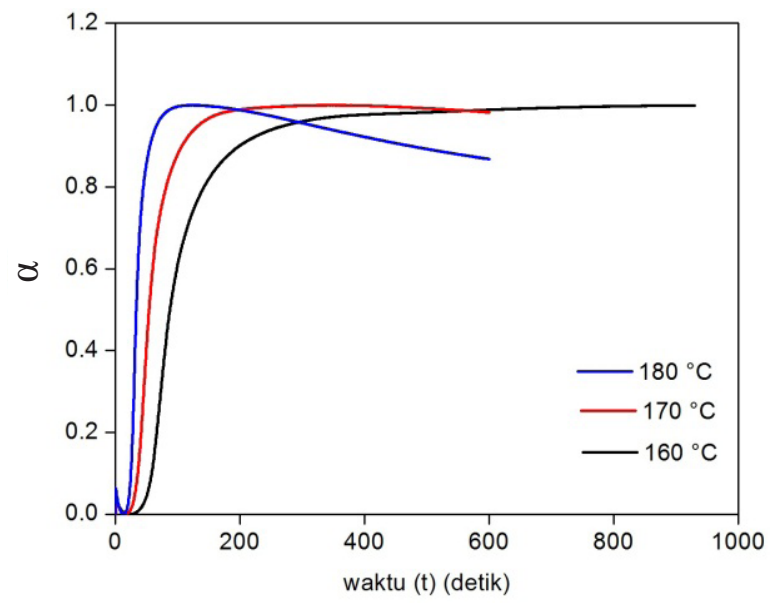

(e)

Gambar 3. Konversi ( $\alpha$ ) vs waktu, (a) R1, (b) R2, (c) R3, (d) R4 dan (e) R5.

karena itu pada suhu tinggi ditemui fenomena reversion seperti ditunjukkan pada Gambar 2(a)(e).

Penambahan ZDEC menghasilkan kurva dengan kemiringan yang lebih terjal (Gambar 3(b)(e)). Hal tersebut berarti laju konversi makin cepat, meskipun penambahan ZDEC meningkatkan viskositas yang ditandai dengan meningkatnya $M L$ dengan kenaikan komposisi ZDEC.

Hubungan kecepatan reaksi $(\mathrm{d} \alpha / \mathrm{dt})$ terhadap konversi $(\alpha)$ digambarkan pada Gambar 4. Keseluruhan kurva berbentuk lonceng asimetris dengan 

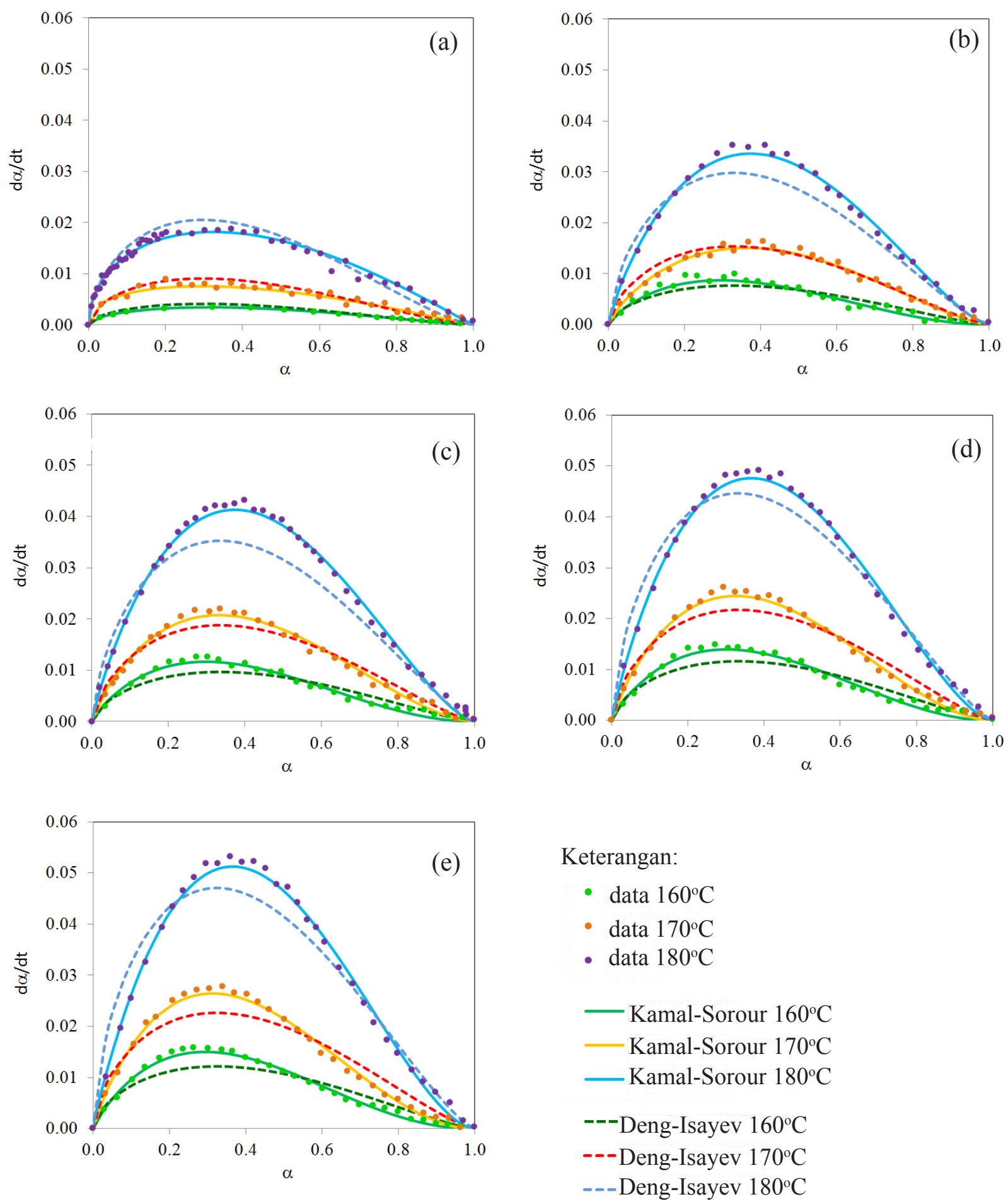

Gambar 4. Hubungan d $\alpha /$ dt versus $\alpha$, (a) R1, (b) R2, (c) R3, (d) R4 dan (e) R5.

ekor disebelah kanan pada sisi konversi tinggi.

Gambar 4(a)-(e) menunjukkan kecepatan reaksi meningkat dengan cepat seiring dengan konversi hingga mencapai nilai maksimum pada rentang $0,2<\alpha<0,4$. Penggunaan akselerator mempengaruhi bentuk kurva d $\alpha /$ dt versus $\alpha$. Kombinasi
MBTS/ZDEC (Gambar 4(b)-(e)) menggeser $(\mathrm{d} \alpha / \mathrm{dt})_{\text {maks }}$ ke arah konversi lebih tinggi terutama pada suhu tinggi. Pada suhu yang lebih tinggi $(\mathrm{d} \alpha / \mathrm{dt})_{\text {maks }}$ makin meningkat untuk seluruh komposisi MBTS/ZDEC. Seperti penjelasan diatas, mobilitas rantai molekul meningkat pada suhu 
tinggi sehingga dapat dengan cepat membentuk jaringan ikatan silang.

Untuk mendeskripsikan data eksperimen digunakan pendekatan model empiris Deng-Isayev dan Kamal-Sorour. Model Deng-Isayev mengoptimasi dua parameter pada persamaan (8), yaitu $k$ dan $n$. Secara umum dapat dilihat pada Gambar 4 bahwa data eksperimen kurang cocok (fit) pada seluruh komposisi MBTS/ZDEC. Kurva prediksi model Deng-Isayev pada R1 terlihat mendahului data eksperimen untuk ketiga suhu, sedangkan fenomena berbeda ditunjukkan oleh R2-R5. Pada suhu rendah $\left(160^{\circ} \mathrm{C}\right)$ prediksi model Deng-Isayev lebih lambat daripada data eksperimen hingga mencapai $\alpha=0,5$ dan kemudian mendahului pada $\alpha>0,5$. Namun pada 170 dan $180^{\circ} \mathrm{C}$ kurva prediksi model Deng-Isayev mendahului data eksperimenhingga $\alpha \approx 0,1$ dan melambat setelah mencapai $\alpha>0,1$. Menurut Arrilaga et al. (2007) orde reaksi $(n)$ yang digunakan pada model tersebut merupakan $n$ rata-rata yang ditentukan tiap suhu. Karena terdapat perbedaan yang besar pada nilai $n$, model akhir hanya cocok terhadap data eksperimen untuk $n$ hasil pencocokan yang serupa dengan nilai $n$ akhir. Oleh karenanya semakin rendah suhu maka $n$ akan semakin rendah pula. Akibatnya pada suhu tinggi kurva prediksi model menunjukkan kinetika yang lebih lambat. Perbedaan nilai $n$ pada suhu lebih rendah tidak terlalu besar sehingga kurva prediksi model berjalan lebih cepat daripada data eksperimen. Konstanta kecepatan reaksi $(k)$ dan orde reaksi $(n)$ hasil pencocokan menggunakan model Deng-Isayev disajikan pada Tabel 2.

Orde reaksi $(n)$ tidak menunjukkan pola tertentu dengan perubahan komposisi MBTS/ZDEC. Hasil yang diperoleh tidak sesuai dengan Khang and Ariff (2012) dimana $n$ bervariasi dengan perubahan jumlah akselerator. Konstanta kecepatan reaksi $(k)$ berbanding lurus dengan suhu, dimana kenaikan suhu akan meningkatkan $k$. Bertambahnya komposisi ZDEC meningkatkan $k$ pada suhu yang sama. Khang and Ariff (2012) memperoleh hasil sebaliknya, yaitu $k$ menurun dengan kenaikan jumlah akselerator. Kenaikan $k$ dimungkinkan merupakan kontribusi dari sinergisme efek aktivitas pasangan MBTS/ZDEC.

Validitas pendekatan model Deng-Isayev terhadap data eksperimen perlu dievaluasi dengan mempertimbangkan hasil pencocokan pada Gambar 4(a)-(e). Yeoh (2012) menyatakan bahwa validitas model Deng-Isayev dapat dievaluasi menggunakan persamaan (8) yang diintegralkan menjadi persamaan (9).

$$
\ln t=\left[\frac{1}{n} \ln \frac{1}{k}\right]+\frac{1}{n}\left[\ln \left(\frac{\alpha}{1-\alpha}\right)\right]
$$

Plot $\ln t$ versus $\ln (\alpha /(1-\alpha))$ merupakan garis lurus yang paralel dengan gradien $1 / n$ untuk masing-masing suhu. Penyimpangan bentuk kurva

Tabel 2. Parameter kinetika model Deng-Isayev.

\begin{tabular}{cccrc}
\hline Kode & $\begin{array}{c}\text { Suhu } \\
\text { Vulkanisasi }\left({ }^{\circ} \mathrm{C}\right)\end{array}$ & $\mathrm{n}$ & $\begin{array}{c}\mathrm{k} \times 10^{-6} \\
(\mathrm{~s})^{-1}\end{array}$ & $\begin{array}{c}\mathrm{E} \\
(\mathrm{kJ} / \mathrm{mol})\end{array}$ \\
\hline R1 & 160 & 2,47 & 2,75 & 324,53 \\
& 170 & & 19,80 & \\
& 180 & & 147,20 & \\
R2 & 160 & 2,94 & 1,07 & 325,04 \\
& 170 & & 8,24 & \\
& 180 & & 57,70 & \\
R3 & 160 & 3,03 & 1,34 & 319,17 \\
& 170 & & 9,98 & \\
& 180 & & 67,17 & 325,65 \\
R4 & 160 & 2,98 & 2,63 & \\
& 170 & & 18,19 & \\
& 180 & & 106,50 & 312,17 \\
R5 & 160 & 2,84 & 5,84 & \\
& 170 & & 199,90 & \\
& 180 & & & \\
\hline
\end{tabular}




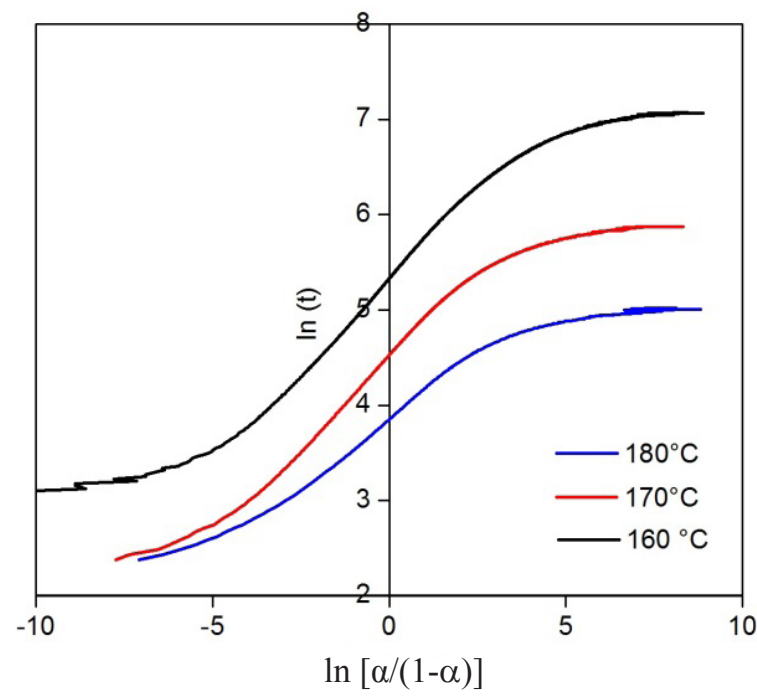

(a)

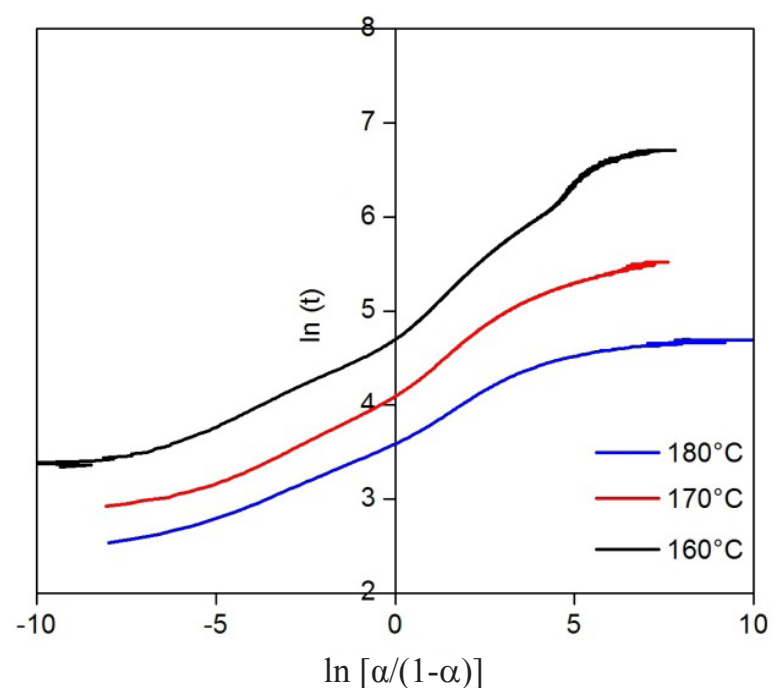

(b)

Gambar 5. Plot $\ln t$ vs $\ln (\alpha /(1-\alpha))$ pada (a) R1 dan (b) R3.

$\ln t$ versus $\ln (\alpha /(1-\alpha))$ menandakan bahwa sistem tidak memenuhi simetri yang diperlukan pada $\alpha=0,5$. Plot $\ln t$ vs $\ln (\alpha /(1-\alpha))$ data eksperimen pada Gambar 5 (tidak disajikan semua) bukan merupakan garis lurus yang paralel untuk ketiga suhu, sehingga sistem tersebut tidak valid didekati dengan model Deng-Isayev.

Pendekatan model Kamal-Sorour merupakan kombinasi antara model orde ke- $n$ dan auto-katalisis. Gambar 4(a)-(e) menunjukkan bahwa data eksperimen dapat dideskripsikan dengan baik oleh model Kamal-Sorour. Hal tersebut berarti proses vulkanisasi NR/EPDM tidak dapat didekati dengan reaksi elementer sederhana, tetapi dengan beberapa reaksi yang terjadi secara simultan atau seri dan reaksi-reaksi tersebut dapat berupa reaksi autokatalisis, seperti dikemukakan oleh Wu et al. (2013).

Konstanta kecepatan reaksi $\left(k_{1}\right.$ dan $\left.k_{2}\right)$ serta orde reaksi ( $m$ dan $n$ ) model Kamal-Sorour dapat dilihat pada Tabel 3. Seperti halnya pada model Deng-Isayev, $k_{1}$ dan $k_{2}$ model Kamal-Sorour juga berbanding lurus dengan kenaikan suhu. Seluruh komposisi MBTS/ZDEC memberikan $k_{2}$ lebih besar daripada $k_{l}$, berarti mekanisme autokatalisis lebih mendominasi daripada mekanisme lainnya. Hasil tersebut sesuai dengan pernyataan Akhilagi et al. (2012) bahwa proses vulkanisasi EPDM mengikuti mekanisme autokatalisis. $k_{2}$ lebih tinggi daripada $k_{l}$ dapat disebabkan oleh viskositas campuran reaksi sangat tinggi pada akhir reaksi pertama (tanpa katalis) sehingga reaktan tidak dapat berpindah tetapi akan diisolasi secara bersama- sama dengan membentuk senyawa yang lebih stabil dan lebih dipersiapkan untuk reaksi katalisis selanjutnya (Kalaee et al., 2011). Kontribusi reaksi autokatalisis $\left(k_{2}\right)$ meningkat hingga komposisi ZDEC mencapai 0,4 phr. Peningkatan tersebut terkait dengan jumlah ikatan silang parsial yang terbentuk pada proses pemanasan awal kompon EPDM, dimana semakin banyak ZDEC terbentuk ikatan silang yang semakin banyak pula. Kerapatan ikatan silang yang tinggi membuat viskositas campuran meningkat, akibatnya jumlah reaktan yang diisolasi semakin banyak. Oleh karena itu yang terlibat dalam reaksi katalisis juga lebih banyak.

Orde reaksi $m$ dan $n$ (Tabel 3) secara keseluruhan tidak menunjukkan pola tertentu terhadap perubahan suhu, namun menunjukkan peningkatan terhadap kenaikan ZDEC. Hal tersebut tidak sejalan dengan hasil yang diperoleh $\mathrm{Wu}$ et al. (2013), Allahbakash et al. (2013), dan Akhilagi et al. (2012). Ketiga publikasi tersebut menyatakan bahwa $m$ dan $n$ tidak tergantung pada suhu dan kandungan bahan dalam kompon. Nilai $n$ lebih besar daripada $m$ menunjukkan ketergantungan reaksi vulkanisasi terhadap reaktan awal dari kompon, jika dibandingkan dengan efek katalisis pada reaksi produk (Wu et al., 2013).

Energi aktivasi $(E)$ kedua model empiris merupakan gradien (slope) dari hubungan linier $\ln k$ versus $1 / T$ pada persamaan (3) (gambar tidak ditampilkan). Energi aktivasi berkaitan dengan kemudahan proses pembentukan ikatan silang. Energi aktivasi menurut pendekatan model Deng- 
Tabel 3. Parameter kinetika model Kamal-Sorour.

\begin{tabular}{cccccccc}
\hline Kode & $\begin{array}{c}\text { Suhu Vulka- } \\
\text { nisasi }\left({ }^{\circ} \mathrm{C}\right)\end{array}$ & $\begin{array}{c}k_{1} \times 10^{-5} \\
(\mathrm{~s})^{-1}\end{array}$ & $\begin{array}{c}\mathrm{k}_{2} \times 10^{-2} \\
(\mathrm{~s})^{-1}\end{array}$ & $m$ & $n$ & $\begin{array}{c}E_{1} \\
(\mathrm{~kJ} / \mathrm{mol})\end{array}$ & $\begin{array}{c}E_{2} \\
(\mathrm{~kJ} / \mathrm{mol})\end{array}$ \\
\hline $\mathrm{R} 1$ & 160 & 0,86 & 1,06 & 0,57 & 1,26 & 297,70 & 124,08 \\
& 170 & 2,59 & 1,88 & 0,44 & 1,07 & & \\
& 180 & 33,60 & 4,87 & 0,52 & 1,07 & & \\
$\mathrm{R} 2$ & 160 & 1,21 & 4,80 & 0,83 & 1,98 & 286,73 & 97,24 \\
& 170 & 10,50 & 6,86 & 0,84 & 1,47 & & \\
& 180 & 40,50 & 15,88 & 0,88 & 1,47 & & \\
$\mathrm{R} 3$ & 160 & 1,06 & 6,78 & 0,86 & 2,03 & 277,89 & 90,43 \\
& 170 & 13,19 & 10,61 & 0,85 & 1,71 & & \\
& 180 & 31,52 & 20,59 & 0,91 & 1,52 & & \\
$\mathrm{R} 4$ & 160 & 0,45 & 8,18 & 0,87 & 2,02 & 355,52 & 91,51 \\
& 170 & 14,67 & 13,70 & 0,89 & 1,84 & & \\
& 180 & 34,93 & 25,15 & 0,93 & 1,61 & & \\
& & & & & & & \\
$\mathrm{R} 5$ & 160 & 1.13 & 9,61 & 0,90 & 2,17 & 365,72 & 93,56 \\
& 170 & 24,26 & 16,25 & 0,92 & 2,01 & & \\
\hline
\end{tabular}

Isayev (Tabel 2) tidak menunjukkan pola tertentu terhadap perubahan rasio MBTS/ZDEC. Energi aktivasi model Kamal-Sorour (Tabel 3) ditemui bahwa $E_{1}$ lebih besar daripada $E_{2}$ pada seluruh komposisi MBTS/ZDEC, artinya reaksi autokatalisis membutuhkan energi yang lebih sedikit daripada reaksi pertama (tanpa katalis). Peranan katalis dalam reaksi kimia adalah mempercepat reaksi dengan menurunkan energi aktivasi. $E_{1}$ dan $E_{2}$ cenderung menurun dengan bertambahnya ZDEC hingga $0,2 \mathrm{phr}$ dan kemudian meningkat dengan penambahan lebih lanjut hingga $0,4 \mathrm{phr}$. Penemuan ini tidak sejalan dengan kenaikan kecepatan reaksi seiring dengan peningkatan jumlah ZDEC. Menurut Khang and Ariff (2012) kekakuan (stiffness) kompon dapat meningkatkan energi aktivasi. R3 dan R4 memiliki kekakuan cukup tinggi karena kerapatan ikatan silangnya tinggi. Oleh karenanya dibutuhkan energi aktivasi yang lebih tinggi untuk mencapai derajat kematangan yang cukup. Secara umum akselerator kombinasi (R2-R5) memberikan $E_{2}$ lebih rendah daripada akselerator tunggal (R1). Hal ini menunjukkan kombinasi MBTS/ZDEC memberikan kemudahan bagi kelangsungan reaksi autokatalisis. Proses vulkanisasi memerlukan energi aktivasi yang rendah serta waktu pematangan yang pendek (Akhilagi et al.,
2012; Ahmadi \& Shojaei, 2013). Berdasarkan pernyataan tersebut, maka R3 merupakan kombinasi yang memberikan energi aktivasi cukup rendah dengan kecepatan reaksi yang tinggi.

\section{KESIMPULAN}

Kinetika reaksi vulkanisasi campuran NR/ EPDM pada berbagai rasio MBTS/ZDEC dipelajari menggunakan pendekatan model empiris Deng-Isayev dan Kamal-Sorour berdasarkan data rheometrik keluaran dari MDR. Kenaikan suhu menurunkan waktu optimum vulkanisasi $\left(\mathrm{t}_{90}\right)$. Data eksperimen dapat dideskripsikan dengan baik dengan model Kamal-Sorour dan mekanisme autokatalisis lebih dominan. Konstanta kecepatan reaksi kedua model empiris berbanding lurus dengan kenaikan suhu. Konstanta kecepatan reaksi autokatalisis $\left(k_{2}\right)$ meningkat seiring dengan kenaikan komposisi ZDEC, sedangkan konstanta reaksi tanpa katalis tidak menunjukkan pola tertentu. Orde reaksi $m$ dan $n$ tidak menunjukkan pola tertentu terhadap perubahan suhu, namun meningkat dengan perubahan jumlah ZDEC. Kombinasi akselerator MBTS/ZDEC menurunkan energi aktivasi reaksi autokatalisis. Rasio MBTS/ZDEC sebesar 1,4/0,2 merupakan kombinasi yang memberikan energi aktivasi cukup rendah dengan ke- 
cepatan reaksi yang tinggi.

\section{UCAPAN TERIMA KASIH}

Publikasi ini merupakan bagian dari penelitian yang dibiayai oleh DIPA Balai Besar Kulit, Karet, dan Plastik tahun anggaran 2013.

\section{DAFTAR PUSTAKA}

Ahmadi, M., \& Shojaei, A. (2013). Cure kinetic and network structure of NR/SBR composites reinforced by multiwall carbon nanotube and carbon blacks. Thermochimica Acta, 566, 238248.

Akhlaghi, S., Kalaee, M., Mazinani, S., Jowdar, E., Nouri, A., Sharif, A., \& Sedaghat, N. (2012). Effect of zinc oxide nanoparticles on isothermal cure kinetics, morphology and mechanical properties of EPDM rubber. Thermochimica Acta, 527, 9198.

Allahbakhsh, A., Mazinani, S., Kalaee, M. R., \& Sharif, F. (2013). Cure kinetics and chemorheology of EPDM/graphene oxide nanocomposites. Thermochimica Acta, 563, 22-32.

Arrilaga, A., Zaldua, A. M., Atxurra, R.M., \& Farid, A. S. (2007). Techniques used for determining cure kinetics of rubber compounds. European Polymer Journal, 43, 4783-4799.

Bianchi, O., Fiorio, R., Martins, J. N., Zattera, A. J., Scuracchio. C. H., \& Canto, L. B. (2009). Crosslinking kinetics of blends of ethylene vinyl acetate and ground tire rubber. Journal of Elastomer and Plastics, 41, 175-189.

Indra, S., Ismail, H., \& Azura, A. R. (2013). Alkanolamide as an accelerator, iller-dispersant and a plasticizer in silica-filled natural rubber compounds. Polymer Testing, 32, 1313-1321.

Indrajati, I. N., \& Sholeh, M. (2014). Pengaruh rasio MBTS/ZDEC pada campuran karet alam dan etilen propilen diena yang dibuat dengan teknik kontrol migrasi curative. Majalah Kulit, Karet, dan Plastik, 30(1), 43-52.

Janković, B. (2010). The kinetic analysis of isothermal curing reaction of an unsaturated polyester resin:
Estimation of the density distribution function of the apparent activation energy. Chemical Engineering Journal, 162, 331-340.

Kalaee, M. R., Akhilaghi, S., Nouri, A., Mazinani, S., Mortezaei, M., Afshari, M., Maostafanezhad, D., Allahbakhsh, A., Dehagi, H. A., Amirsadri, A., \& Gohari, D. P. (2011). Effect of nano-sized calcium carbonate on cure-kinetics and properties of polyester/epoxy blend powder coatings. Progress in Organic Coatings, 71, 173-180.

Khang, T. H., \& Ariff, Z. M. (2012). Vulcanization kinetic study of natural rubber compounds having different formulation variables. Journal of Thermal Analysis and Calorimetry, 109, 1545-1553.

Leroy, E., Souid, A., \& Deterre, R. (2013a). A continuous kinetic model of rubber vulcanization predicting induction and reversion. Polymer Testing, 32, 575582.

Leroy, E., Souid, A., Sarda, A., \& Deterre, R. (2013b). A knowledge based approach for elastomer cure kinetic parameters estimation. Polymer Testing, $32,9-14$.

Marzocca,A. J., \& Mansilla, M.A.(2006). Vulcanization kinetic of styrene-butadiene rubber by sulfur/ TBBS. Journal of Applied Polymer Science, 101, 35-41.

Milani, G., \& Milani, F. (2013). Kinetic finite element model to optimize sulfur vulcanization to extruded EPDM weathe-strips. Polymer Engineering and Science, 53(2), 353-369.

Wu, J., Xing, W., Huang, G., Li, H., Tang, M., Wu, S., \& Liu, Y. (2013). Vulcanization kinetics of graphene/ natural rubber nanocomposites. Polymer, 54, 3314-3323.

Yeoh, O. H. (2012). Mathematical modeling of vulcanization characteristic. Rubber Chemistry and Technology, 85(3), 482-492. 